Opinion

\title{
When Is Arteriovenous Fistula Dangerous for Hemodialysis Patients?
}

\author{
Jan Malík (D)
}

check for

Citation: Malík, J. When Is

Arteriovenous Fistula Dangerous for Hemodialysis Patients? Kidney Dial. 2022, 2, 82-84. https://doi.org/ $10.3390 /$ kidneydial2010010

Academic Editor: Manfred Hecking

Received: 19 January 2022

Accepted: 10 February 2022

Published: 14 February 2022

Publisher's Note: MDPI stays neutral with regard to jurisdictional claims in published maps and institutional affiliations.

Copyright: (C) 2022 by the author. Licensee MDPI, Basel, Switzerland. This article is an open access article distributed under the terms and conditions of the Creative Commons Attribution (CC BY) license (https:// creativecommons.org/licenses/by/ $4.0 /)$.
Third Department of Internal Medicine, General University Hospital, First Faculty of Medicine, Charles University, 12808 Prague, Czech Republic; jan.malik@vfn.cz; Tel.: +420-224962363; Fax: +420-224962765

Abstract: Hemodialysis arteriovenous fistula is a shortcut of the systemic circulation and sometimes fistula flow exceeds $2 \mathrm{~L} / \mathrm{min}$. Possible hemodynamic and clinical consequences are discussed.

Keywords: arteriovenous fistula; heart failure; pulmonary hypertension

\section{Introduction}

Functioning vascular access is a condition of functioning hemodialysis. Nowadays, the following three types of access into the blood stream are used: hemodialysis catheter, naive arteriovenous fistula (AVF), or arteriovenous graft (AVG). The blood flow through the hemodialysis device is usually set to $300-400 \mathrm{~mL} / \mathrm{min}$; the blood flow volume at entry must be even higher to prevent recirculation $(>500 \mathrm{~mL} / \mathrm{min})$. The creation of both AVFs and AVGs increases the flow through the extremity by 10-30 times, and it reaches 500-2000 $\mathrm{mL} / \mathrm{min}$, sometimes even more. When we consider the normal resting cardiac output (i.e., the amount of blood pumped by the heart in a minute), 4-6 L/min, it then becomes apparent that an AVF or AVG graft could interfere with the human circulation.

Considering the hemodynamic impact of hemodialysis access only, a catheter may seem to be the safest type. This, however, is not true; several studies revealed higher mortality in patients hemodialyzed through catheters [1]. Infective complications are responsible for the higher mortality, and also include life-threatening bacterial endocarditis [2]. The optimal blood flow of an AVF is between 500 and $1500 \mathrm{~mL} / \mathrm{min}$; for AVGs, the lower limit is $600 \mathrm{~mL} / \mathrm{min} \mathrm{[3].} \mathrm{Arteriovenous} \mathrm{access} \mathrm{blood} \mathrm{flow} \mathrm{(Qa)} \mathrm{is} \mathrm{determined} \mathrm{by} \mathrm{the} \mathrm{systemic}$ arterial pressure and the access resistance. The latter is mainly influenced by the size of the arteriovenous anastomosis and the feeding artery (or of a stenosis, if present). Therefore, upper-arm AVFs, especially brachio-cephalic AVFs, usually have higher Qa [4]. The flow volume increases dramatically immediately after the creation of any of these arteriovenous accesses, and reaches a plateau within 3-6 months. While the flow through the AVG is usually stable, thanks to the rigid graft, this is not true for AVFs. In AVFs, continuous dilatation of the feeding artery (remodeling), driven by the high wall shear stress, leads to dilatation of the arteriovenous anastomosis, and, thus, to a decrease in access resistance. Indeed, flow over $2000 \mathrm{~mL} / \mathrm{min}$ develops almost exclusively in AVFs. These high-flow fistulas are known to be associated with heart failure in some patients [4].

There are the following two important questions: What is the safe upper limit of Qa? Do the high, or very high, Qa values matter if the patient is asymptomatic?

\section{Safe Upper Limit of Qa}

AVF creation with "normal" Qa leads to worsening of the left ventricular diastolic function, and to an increase in B-type natriuretic peptide (BNP, a marker of heart failure) $[5,6]$. An increase in BNP depends on the Qa value. An interesting study, published by B. Dundon et al. [7], used cardiac magnetic resonance before and 6 months after AVF creation. At the follow-up visit, the patients had a mean Qa value of $1158 \mathrm{~mL} / \mathrm{min}$, and 
significantly higher left ventricular mass and dilatation of all cardiac chambers. A recent study reported similar results [8].

The term "high-flow AVF" is not uniformly used for patients with signs of heart failure (e.g., leg oedema, ascites, and hypotension), especially those with symptoms that develop sooner than signs (e.g., shortness of breath, bendopnoea, and fatigue), or for those with Qa $>1500-2000 \mathrm{~mL} / \mathrm{min}$ or when the ratio of Qa and cardiac output exceeds 30\% [4]. These AVFs bring a higher risk of heart failure, but are frequently asymptomatic, or the patients suffer from orthopedic limitations, frailty, neuropathy, etc., that prevent the manifestation of exercise-induced symptoms. Even sooner than exercise-induced complaints, we could observe echocardiographical changes that mirror altered hemodynamics, such as the dilatation of heart cavities, and the development of secondary valvular regurgitation or of diastolic dysfunction. Although they are evidently a mild stage of heart failure, the current guidelines reserve the term "heart failure" for symptomatic patients only (at least temporarily), and call these abnormalities "heart failure precursors". Several studies tested the effects of Qa reduction, or even AVF ligation $[9,10]$. They reported decreases in left ventricular mass, the size of cardiac chambers, and pulmonary hypertension, and improvements in left ventricular diastolic function, and even slightly improved brain oxygenation after Qa reduction.

Some trials reported a prediction of higher mortality in hemodialysis patients with left ventricular hypertrophy [11], left atrial dilatation [12], or with pulmonary hypertension [13]. All these parameters are influenced by AVF, especially when Qa is high. However, we have no formal proof of the concept that high Qa increases mortality.

There is general agreement that symptomatic, high-flow AVFs should be treated by surgical flow reduction in hemodialysis patients [4], and some experts recommend AVF ligation after successful kidney transplant. Surgical Qa reduction in asymptomatic, high-flow AVF patients on hemodialysis has not been reported, except for in our two articles. We indicated flow reduction, even in asymptomatic patients who have left ventricular hypertrophy or pulmonary hypertension. The effects on the heart were the same in symptomatic and asymptomatic patients. This could also be important in light of the finding that AVF is frequently created too early before the real need for hemodialysis, and, in some subjects, it is never used at all.

The $\mathrm{Qa} / \mathrm{CO}$ ratio seems to increase exponentially when Qa exceeds $2 \mathrm{~L} / \mathrm{min}$. We can cautiously consider that this is the upper safe Qa limit for most patients. However, the limit is significantly lower in patients with heart failure, and this is very frequent in the hemodialysis population.

The current guidelines are not in agreement regarding the indication of flow-reducing surgery. The European Society of Vascular Surgery guidelines recommend that dialysis patients with an access flow above $1500 \mathrm{~mL} / \mathrm{min}$ should be regularly monitored by means of flow measurements, echocardiography, and evaluating the clinical signs of heart failure [14]. On the other hand, the Spanish guidelines suggest AVF flow reduction when Qa is $>2000$ $\mathrm{mL} / \mathrm{min}$ or $\mathrm{CPR}>30 \%$, to reduce the risk of high-output heart failure [15]. Importantly, AVF creation must be thoroughly considered, especially in patients with very low ejection fractions and shortness of breath [16].

Funding: This research was funded by the project MH CZ-DRO (General University Hospital in Prague-VFN, 00064165).

Institutional Review Board Statement: Not applicable.

Informed Consent Statement: Not applicable.

Data Availability Statement: Not applicable.

Conflicts of Interest: The author declares no conflict of interest. 


\section{References}

1. Roca-Tey, R.; Arcos, E.; Comas, J.; Cao, H.; Tort, J.; The Catalan Renal Registry Committee. Starting Hemodialysis with Catheter and Mortality Risk: Persistent Association in a Competing Risk Analysis. J. Vasc. Access 2015, 17, 20-28. [CrossRef] [PubMed]

2. Chaudry, M.S.; Carlson, N.; Gislason, G.; Kamper, A.-L.; Rix, M.; Fowler, V.G., Jr.; Torp-Pedersen, C.; Bruun, N.E. Risk of Infective Endocarditis in Patients with End Stage Renal Disease. Clin. J. Am. Soc. Nephrol. 2017, 12, 1814-1822. [CrossRef] [PubMed]

3. Fila, B. Quality indicators of vascular access procedures for hemodialysis. Int. Urol. Nephrol. 2021, 53, 497-504. [CrossRef] [PubMed]

4. Malik, J.; Valerianova, A.; Tuka, V.; Trachta, P.; Bednarova, V.; Hruskova, Z.; Slavikova, M.; Rosner, M.H.; Tesar, V. The effect of high-flow arteriovenous fistulas on systemic haemodynamics and brain oxygenation. ESC Hear. Fail. 2021, 8, $2165-2171$. [CrossRef] [PubMed]

5. Iwashima, Y.; Horio, T.; Takami, Y.; Inenaga, T.; Nishikimi, T.; Takishita, S.; Kawano, Y. Effects of the creation of arteriovenous fistula for hemodialysis on cardiac function and natriuretic peptide levels in CRF. Am. J. Kidney Dis. 2002, 40, 974-982. [CrossRef] [PubMed]

6. Malík, J.; Tuka, V.; Krupickova, Z.; Chytilova, E.; Holaj, R.; Slavikova, M. Creation of dialysis vascular access with normal flow increases brain natriuretic peptide levels. Int. Urol. Nephrol. 2009, 41, 997-1002. [CrossRef] [PubMed]

7. Worthley, M.; Dundon, B.; Torpey, D.; Nelson, A.; Wong, D.; Duncan, R.; Meredith, I.; Faull, R.; Worthley, S. The deleterious effects of arteriovenous fistula-creation on the cardiovascular system: A longitudinal magnetic resonance imaging study. Int. J. Nephrol. Renov. Dis. 2014, 7, 337-345. [CrossRef] [PubMed]

8. Pucchio, A.; McIntyre, C.; Lok, C.; Moist, L. Cardiac implications of upper-arm arteriovenous fistulas: A case series. J. Vasc. Access 2022. [CrossRef] [PubMed]

9. Rao, N.N.; Stokes, M.B.; Rajwani, A.; Ullah, S.; Williams, K.; King, D.; Macaulay, E.; Russell, C.H.; Olakkengil, S.; Carroll, R.P.; et al. Effects of Arteriovenous Fistula Ligation on Cardiac Structure and Function in Kidney Transplant Recipients. Circulation 2019, 139, 2809-2818. [CrossRef] [PubMed]

10. Hetz, P.; Pirklbauer, M.; Müller, S.; Posch, L.; Gummerer, M.; Tiefenthaler, M. Prophylactic Ligature of AV Fistula Prevents High Output Heart Failure after Kidney Transplantation. Am. J. Nephrol. 2020, 51, 511-519. [CrossRef] [PubMed]

11. Zoccali, C.; Benedetto, F.A.; Mallamaci, F.; Tripepi, G.; Giacone, G.; Stancanelli, B.; Cataliotti, A.; Malatino, L.S. Left ventricular mass monitoring in the follow-up of dialysis patients: Prognostic value of left ventricular hypertrophy progression. Kidney Int. 2004, 65, 1492-1498. [CrossRef] [PubMed]

12. Sharma, R.; Pellerin, D.; Gaze, D.C.; Mehta, R.L.; Gregson, H.; Streather, C.P.; Collinson, P.O.; Brecker, S.J. Mitral Peak Doppler E-wave to Peak Mitral Annulus Velocity Ratio Is an Accurate Estimate of Left Ventricular Filling Pressure and Predicts Mortality in End-stage Renal Disease. J. Am. Soc. Echocardiogr. 2006, 19, 266-273. [CrossRef] [PubMed]

13. Yigla, M.; Abassi, Z.; Reisner, S.A.; Nakhoul, F. Pulmonary Hypertension in Hemodialysis Patients: An Unrecognized Threat. Semin. Dial. 2006, 19, 353-357. [CrossRef] [PubMed]

14. Schmidli, J.; Widmer, M.K.; Basile, C.; de Donato, G.; Gallieni, M.; Gibbons, C.P.; Haage, P.; Hamilton, G.; Hedin, U.; Kamper, L.; et al. Editor's Choice-Vascular Access: 2018 Clinical Practice Guidelines of the European Society for Vascular Surgery (ESVS). Eur. J. Vasc. Endovasc. Surg. 2018, 55, 757-818. [CrossRef] [PubMed]

15. Ibeas, J.; Roca-Tey, R.; Vallespín, J.; Moreno, T.; Moñux, G.; Martí-Monrós, A.; Del Pozo, J.L.; Gruss, E.; De Arellano, M.R.; Fontseré, N.; et al. Fe de errores de «Guía Clínica Española del Acceso Vascular para Hemodiálisis». Nefrología 2019, 39, 680-682. [CrossRef] [PubMed]

16. Malik, J.; Lomonte, C.; Rotmans, J.; Chytilova, E.; Roca-Tey, R.; Kusztal, M.; Grus, T.; Gallieni, M. Hemodialysis vascular access affects heart function and outcomes: Tips for choosing the right access for the individual patient. J. Vasc. Access 2020, $22,32-41$. [CrossRef] [PubMed] 